\title{
Levels of Selected Toxic and Essential Elements in Fish and Oysters from Western Indian Ocean, Coast of Tanzania
}

\author{
Daniel A Shilla ${ }^{1}$ * and Shovi F Sawe ${ }^{2}$ \\ ${ }^{I}$ Department of Aquatic Science and Fisheries Technology, University of Dar es Salaam, P. O. \\ Box 35064, Dar es Salaam, Tanzania. E-mail: dshilla@udsm.ac.tz \\ ${ }^{2}$ Department of Research and Development, Tanzania Atomic Energy Commission, P. O. Box 743, \\ Arusha,Tanzania.E-mail: shovisawe@yahoo.co.uk \\ Received 29 Dec 2020, Revised 15 May 2021, Accepted 21 May 2021, Published May 2021
}

DOI: https://dx.doi.org/10.4314/tjs.v47i2.27

\begin{abstract}
Concentrations of toxic and essential elements in selected finfish and shellfish collected from Dar es Salaam and Tanga, Indian Ocean coast of Tanzania are presented. The elemental concentrations were determined using Energy Dispersive X-ray Fluorescence (EDXRF) spectrometer coupled with X-lab Pro ${ }^{\mathrm{TM}}$ software. The mean concentrations of metals observed in finfish and shellfish collected from Tanga ranged from 3.40-5.75, 1.8-37.17, 3.5-7.1, 0.6-1.3, 0.53-0.73 and 16.80$96.70 \mathrm{mg} \mathrm{kg}^{-1}$ for $\mathrm{As}, \mathrm{Cu}, \mathrm{Mn}, \mathrm{Ni}, \mathrm{Pb}$ and $\mathrm{Zn}$, respectively. For Dar es Salaam, the mean concentrations of metals ranged from 3.34-9.46, 2.90-30.53, 3.4-6.9, 0.7-1.0, 0.57-0.80 and $14.2-100.90 \mathrm{mg} \mathrm{kg}^{-1}$ for $\mathrm{As}, \mathrm{Cu}, \mathrm{Mn}, \mathrm{Ni}, \mathrm{Pb}$ and $\mathrm{Zn}$, respectively. Thumbprint emperor showed the highest levels of $\mathrm{Cu}$ and $\mathrm{Ni}$; octopus showed the highest values of $\mathrm{As}$ and $\mathrm{Pb}$, while sardines showed the highest level of Mn. Oysters, used as pollution indicators in this study showed the highest elemental concentrations and exceeded their mean levels in finfish from Dar es Salaam by factors of $1.30,7.15,6.27,2.72,1.29$ and 35.57 for $\mathrm{As}, \mathrm{Cu}, \mathrm{Mn}, \mathrm{Ni}, \mathrm{Pb}$ and $\mathrm{Zn}$, respectively. In samples from Tanga, the metal concentrations in oysters were several times higher $(3.76,17.68$, $1.12,3.89,1.88$ and 66.92 for $\mathrm{As}, \mathrm{Cu}, \mathrm{Mn}, \mathrm{Ni}, \mathrm{Pb}$ and $\mathrm{Zn}$ ) than in finfish, respectively. Based on metal concentrations in oysters, it can be concluded that coastal waters are contaminated with heavy metals. However, with an exception of arsenic and copper, the elemental levels in finfish are within the maximum permissible levels recommended by various international standards and guidelines.
\end{abstract}

Keywords: Finfish, toxic elements, essential elements, pollution, EDXRF.

\section{Introduction}

Fish is consumed in many countries worldwide because of their high protein, essential amino acids, vitamin, and essential mineral contents (Daviglus et al. 2002, Verbeke et al. 2007). This vital resource is experiencing threats because persistent pollutants of agriculture, urban and industrial origins are contaminating the marine environment. Contamination of marine coastal environment by heavy metals is of great concern due to their toxicity, persistence, nondegradability, bioaccumulation, long biological half life, and public food safety (Zhou et al. 2001, Alhas et al. 2009, Jonathan et al. 2017, Ross et al. 2017). Some metals (e.g. Cu, Mn, $\mathrm{Ni}$, and $\mathrm{Zn}$ ) are essential since they play important roles in biological systems, while others (e.g. $\mathrm{As}, \mathrm{Cd}, \mathrm{Pb}$ ) are non-essential even at small concentrations because they are toxic (Turkmen et al. 2008). On human health, toxic elements bio-accumulated in seafood can cause 
damage to mental and central nervous system. High intake of essential metals can also lead to toxic effects (Turkmen et al. 2008, Uysal 2011). Studies have shown that small fish and oysters become enriched with the accumulated substances in polluted aquatic systems, so they can be used in studying environmental changes, and as pollution indicators (Ashraf et al. 2012).

In Tanzanian, seafood and fisheries in general are economically important in terms of food supply, employment generation, income generation, and government revenue (URT 2001, URT 2010, URT 2014). The importance of fisheries in Tanzania is recognized across multiple sectors. The National Strategy for Growth and Poverty Reduction recognizes fisheries as having the potential to contribute to improving livelihoods and nutrition (URT 2010). The 2006-2015 National Water Sector Development Strategy highlights the important links between water quality and fisheries, and the importance of fish to sustainable livelihoods (URT 2001).

Due to undesirable health effects that may result from consumption of contaminated seafood, many countries and international organizations have set guidelines for the maximum permissible levels of heavy metals in seafood. In addition, WHO has established the Provisional Table Weekly Intake (PTWI), per $\mathrm{kg}$ of body weight (mg/person/week) to describe the risk from metals intake through ingestion (CAC 1995). Therefore, it is vital that the levels of heavy metals are monitored in the coastal zones, where most fishery and farming activities occur in order to protect the health of seafood consumers. In view of that, an investigation of heavy metal concentrations in edible parts of six commercially important fish species (finfish and shellfish) in Dar es Salaam and Tanga Tanzania was undertaken during this study. Other studies have shown that aquatic invertebrates such as oysters can be used to assess the heavy metals pollution status of marine ecosystems in order to evaluate potential risks to human health (Olgunoglu et al. 2015, Chinnadurai et al. 2016, Welty et al. 2018). Therefore, oysters were included in this study as pollution indicators only since consumption of oysters in Tanzanian population is not common. The aim of this study was to determine the concentrations of heavy metals namely arsenic (As), copper $(\mathrm{Cu})$, manganese $(\mathrm{Mn})$, nickel $(\mathrm{Ni})$, lead $(\mathrm{Pb})$ and zinc $(\mathrm{Zn})$ in the muscles of oysters and some commercial finfish namely; mackerel, sardines, thumbprint emperor, grouper, octopus and jacks available in Tanzanian coastal markets. These concentrations were then compared against their maximum permissible levels in seafood. Results for most species and in particular oysters are reported for the first time.

\section{Materials and Methods \\ Description of study site}

Dar es Salaam region is located at $6^{\circ} 48^{\prime} \mathrm{S}$, $39^{\circ} 17^{\prime} \mathrm{E}$, while Tanga region is located at $5.0889^{\circ} \mathrm{S}, 39.1023^{\circ} \mathrm{E}$ on the Indian Ocean coast of East Africa (Figure 1). The two regions have in common major port operations, industrial and fishing activities, rapid population growth and urban agriculture, among others. Both areas are characterized by seasonal variations in water circulation connected with the periods of northeast and southeast monsoon seasons. The climate is tropical, with hot weather throughout the year temperatures ranging from 26 to $35{ }^{\circ} \mathrm{C}$ and there are two rainy seasons: long rains in March-May and short rains in NovemberDecember. The industries in these areas manufacture a variety of goods for the local and foreign markets, and they include: distilleries, breweries, manufacturers of cigarettes, cement, paints, pharmaceuticals, plastic, metal products, steel, chemicals, confectionery, food products, timber and wood products, petroleum products, dairy products, batteries, printing, publishing and paper products, among others (Mshana and Sekadende 2014). Pollutants released from the aforementioned activities can find their ways into the coastal waters and affect the quality of seafood and health of their consumers.

Sample collection, treatment and analysis 
Six fish species (finfish and shellfish) were collected in March 2020 from the Indian Ocean Coast of Dar es Salaam and Tanga, Tanzania (Figure 1) from Kunduchi and Deep sea fish markets for Dar es Salaam and Tanga, respectively. A mix of different sizes was sampled from fish markets to represent what is consumed by the public. Oysters (genus Pinctada) were collected by hand at the shoreline of Oyster Bay Dar es Salaam and near Deep sea fish market in Tanga, while samples for finfish and octopuses were collected from commercial fishing boats at Kunduchi and Deep sea landing sites. Samples were collected depending on the availability during sampling dates. Ten samples were collected for each fish species. An exception was for octopus which two samples weighing 2 $\mathrm{kg}$ were collected from each station. For sardines, samples were collected by weight (3$4 \mathrm{~kg}$ ) because of their small body size. About 4 $\mathrm{kg}$ of oysters from both Dar es Salaam and Tanga were collected in order to ensure sample reliability.

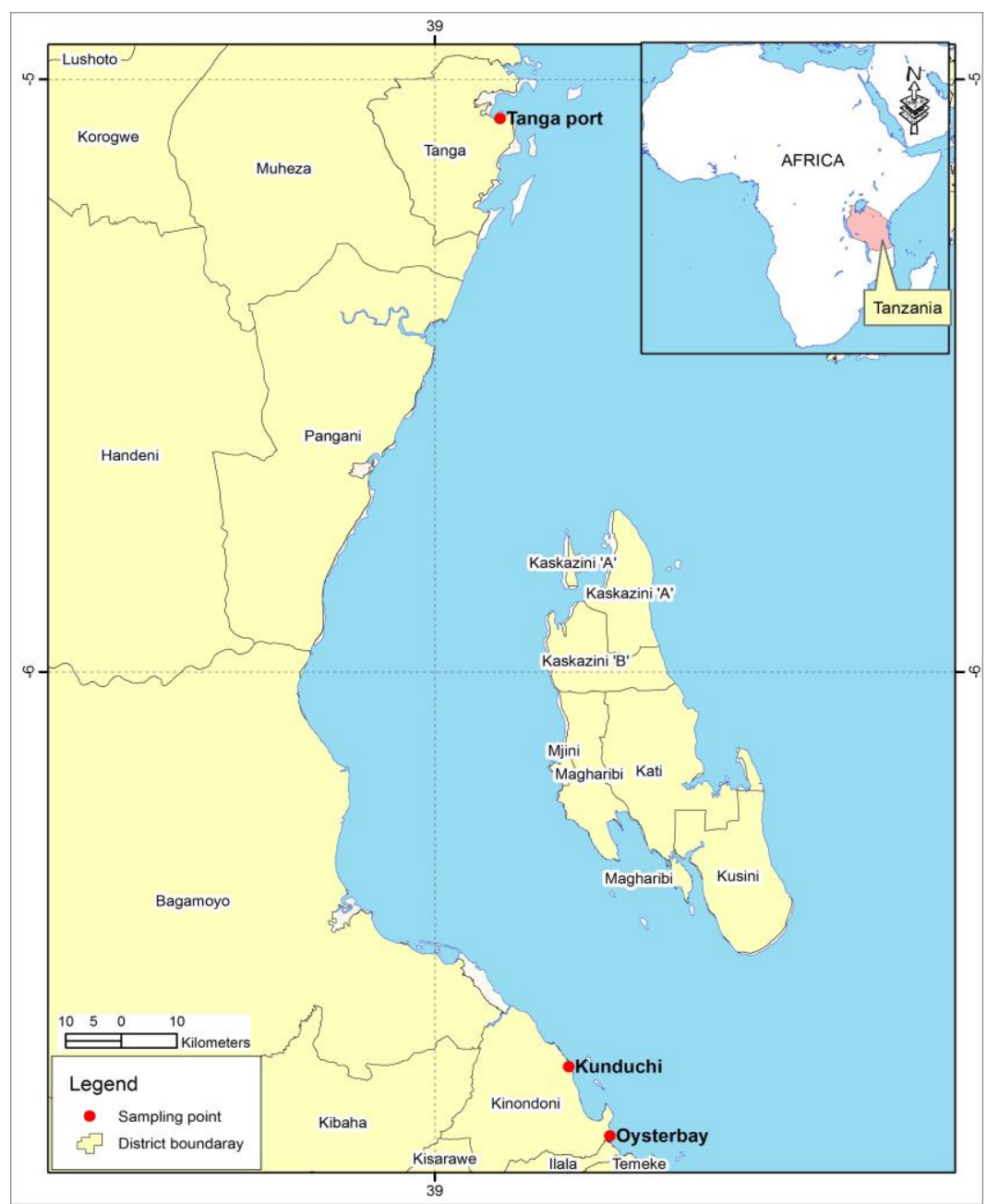

Figure 1: A map showing the coastline of Tanzania with sampling sites. 
Collected samples were stored in cool boxes and transported to the University of Dar es Salaam fisheries laboratory in Kunduchi where they were rinsed with distilled water (EPA 2000). Finfish and shellfish samples were dissected using Tamsco Fish Dissection Kit to get edible tissues to be analyzed for heavy metals. Prior to preparing each composite sample, utensils and containers were cleaned thoroughly with a detergent solution $\left(\mathrm{Omo}^{\circledR}\right)$, rinsed with tap water, soaked in $0.5 \%$ nitric acid, and then rinsed with distilled water (EPA 2000). Soft tissues of oysters were analyzed, while their shells were disposed of without been analyzed. All the samples were freeze-dried and ground before elemental analysis. Briefly, dried samples were grinded or segregated using pestle and mortar and the resulting powder was placed in plastic zip bags or desiccators to prevent absorption of moisture as described in Holynsca and Jasion (1986). Aliquots of about $4 \mathrm{~g}$ each of dried and sieved samples were mixed with about $0.9 \mathrm{~g}$ of cellulose binder, homogenized in a pulverizer, and pressed into a pellet of approximately 32 $\mathrm{mm}$ diameter. The obtained pellets were then placed in the sample chamber of a well calibrated Energy Dispersive X-Ray
Fluorescence (EDXRF) spectrometer coupled with X-lab Pro ${ }^{\mathrm{TM}}$ software for the determination of total metals concentrations using the equation $C_{i}=\left(K_{i} \times I_{i} \times M_{i}\right)$ described in Rousseau et al. (1996). Where $C_{i}=$ elemental concentration (e.g. $\mathrm{mg} \mathrm{kg}^{-1}$ ) of element ' $\mathrm{i}$ '; $\mathrm{K}_{\mathrm{i}}=$ the calibration constant for element ' $\mathrm{i}$ ' $(\% / \mathrm{kcps})$; $\mathrm{I}_{\mathrm{i}}=$ net peak intensity for analyte element ' $\mathrm{i}$ ' (kcps) and $\mathrm{M}_{\mathrm{i}}=$ matrix correction term for element ' $i$ '.

\section{Analytical quality control}

The accuracy of the method was checked by analyzing the certified reference material (CRM) IAEA-436 (trace elements and methyl mercury in tuna fish flesh homogenate). About $4 \mathrm{~g}$ of the CRM was mixed with about $0.9 \mathrm{~g}$ of cellulose binder, homogenized in a pulverizer, and pressed into a pellet of approximately 32 $\mathrm{mm}$ diameter. The pellets of the CRM were then analyzed in the same way as the fish samples. Experimental values were compared with the certified elemental concentrations as shown in Table 1. The experimental concentration values agreed well with the recommended values demonstrating the validity of results.

Table 1: Elemental concentrations in IAEA-436. Results obtained during this study are reported in $\mathrm{mg} \mathrm{kg}^{-1}$ dry weight $(\mathrm{dw})$ with \% recovery (accuracy) in the last column

\begin{tabular}{cccc}
\hline Element & $\begin{array}{c}\text { Recommended value }(95 \% \\
\text { confidence interval) }\end{array}$ & This study $(\mathrm{n}=3)$ & $\begin{array}{c}\text { \% Recovery } \\
\text { (Accuracy) }\end{array}$ \\
\hline $\mathrm{Al}$ & 3.06 & 2.92 & $95.4 \%$ \\
$\mathrm{As}$ & 1.98 & 1.8 & $90.9 \%$ \\
$\mathrm{Cr}$ & 0.194 & 0.19 & $97.9 \%$ \\
$\mathrm{Cu}$ & 1.73 & 1.5 & $86.7 \%$ \\
$\mathrm{~Pb}$ & 0.0124 & 0.0104 & $84.1 \%$ \\
$\mathrm{Fe}$ & 89.3 & 86.6 & $96.9 \%$ \\
$\mathrm{Mn}$ & 0.222 & 0.194 & $87.4 \%$ \\
$\mathrm{Ni}$ & 0.07 & 0.06 & $89.0 \%$ \\
$\mathrm{Zn}$ & 19.0 & 18.8 & $98.9 \%$ \\
\hline
\end{tabular}

\section{Data analysis}

Mean concentrations \pm standard deviations (SD) in $\mathrm{mg} / \mathrm{kg}$ dry weight (dw) were determined. Statistical analyses were performed using PRIMER 6 Version 6.1.16 \& PERMANOVA+ Version 1.0.6 software and excel spread sheet. One-way analysis of variance (ANOVA) was used to assess whether 
Shilla and Sawe - Levels of selected toxic and essential elements in fish and oysters ...

the average of elemental concentrations varied significantly among sites. A p-value less than $0.05(\mathrm{p}<0.05)$ was considered statistically significant.

\section{Results and Discussion Concentrations of heavy metals in fish and oysters}

The mean concentrations and standard deviations of concentrations of $\mathrm{As}, \mathrm{Cu}, \mathrm{Mn}, \mathrm{Ni}$ and $\mathrm{Zn}$ in the tissues of the analyzed six fish species are presented in Tables 2 and 3 as mean values and standard deviations. Results are presented in $\mathrm{mg} \mathrm{kg}^{-1} \mathrm{dw}$. Elemental concentrations in oysters from Dar es Salaam exceeded their mean values in fish by factors of $1.30,7.15,6.27,2.72,1.29$ and 35.57 for $\mathrm{Cu}$, $\mathrm{Mn}, \mathrm{Ni}$, and $\mathrm{Zn}$, respectively (Tables 2 ). The same trend was observed for Tanga where elemental concentrations in oysters exceeded their mean values in other species by factors of 3.76, 17.68, 1.12, 3.89, 1.88 and 66.92 times for $\mathrm{As}, \mathrm{Cu}, \mathrm{Mn}, \mathrm{Ni}, \mathrm{Pb}$ and $\mathrm{Zn}$, respectively (Tables 3). The results indicate that no single type of fish was consistently high for all the analyzed heavy metals.

Looking at one element after another, analyzed fish and the sampling locations; the highest level of arsenic $\left(9.46 \mathrm{mg} \mathrm{kg}^{-1}\right.$ ) in samples from Dar es Salaam was measured in octopus. Also, the highest level of arsenic (5.75 $\mathrm{mg} \mathrm{kg}^{-1}$ ) in samples from Tanga was measured in octopus. On the other hand, lowest levels of As were observed in mackerel from both Dar es Salaam (3.34 $\mathrm{mg} \mathrm{kg}^{-1}$ ) and Tanga (3.4 mg $\left.\mathrm{kg}^{-1}\right)$. Various literatures have reported arsenic levels in fish muscles. For example, Mania et al. (2015) reported mean As value of $0.46 \mathrm{mg}$ $\mathrm{kg}^{-1}$; De Gieter (2002) reported values $>20 \mathrm{mg}$ $\mathrm{kg}^{-1}$ wet weight (ww), while Mziray and Kimirei (2016) reported As values ranging from 3.43 to $18.52 \mu \mathrm{g} \mathrm{g}^{-1}$. Arsenic has been reported to be a trace element of nutritional importance to humans but its functions in the biological systems is not clear (Duruibe et al. 2007). It is possibly carcinogenic and high- level exposure can cause death (Mziray and Kimirei 2016). The mean concentrations of arsenic in both locations were above the permissible level of $0.1 \mathrm{mg} \mathrm{kg}^{-1}$ recommended by FAO/WHO (2018). This finding is in agreement with the study by Mziray and Kimirei (2016) who found out that the levels of arsenic in fish from Kunduchi fish market in Dar es Salaam exceeded the recommended levels.

Copper was the highest $\left(37.17 \mathrm{mg} \mathrm{kg}^{-1}\right)$ in thumbprint emperor from Tanga. The lowest level of copper in samples from Tanga $(1.8 \mathrm{mg}$ $\mathrm{kg}^{-1}$ ) was found in jacks (kolekole), while in samples from Dar es Salaam the lowest level of copper (2.9 mg kg-1) was found in sardines. Different authors have reported $\mathrm{Cu}$ levels in the literature as ranging from 0.5 to $1.1 \mathrm{mg} \mathrm{kg}^{-1}$ ww in fish from Ria de Averio, Portugal (Perez et al. 2001), 1.65-9.17 $\mu \mathrm{g} \mathrm{g}^{-1}$ (Mziray and Kimirei 2016), 0.7 to $27.0 \mathrm{mg} \mathrm{kg}^{-1} \mathrm{dw}$ (Tapia et al. 2006), 0.15 to $24 \mathrm{mg} \mathrm{kg}^{-1}$ (Sivaperumal et al. 2007) and below $2.64 \mathrm{mg} \mathrm{kg}^{-1}$ (Fernandes et al. 2007) in the muscles of fish; while 3.1$323.4 \mathrm{mg} \mathrm{kg}^{-1}$ (Tapia et al. 2006) and 51-544 $\mathrm{mg} \mathrm{kg}^{-1}$ with a mean of $253.68 \mathrm{mg} \mathrm{kg}^{-1}$ in the livers of fish (Fernandes et al. 2007). Our results show that thumbprint emperor from Tanga and grouper from Dar es Salaam slightly exceeded the limit of $30 \mu \mathrm{g} \mathrm{Cu} \mathrm{g}^{-1}$ set by FAO (1993).

Manganese was highest in sardines from both Dar es Salaam $\left(6.9 \mathrm{mg} \mathrm{kg}^{-1}\right)$ and Tanga (7.1 $\mathrm{mg} \mathrm{kg} \mathrm{kg}^{-1}$ ). The lowest value was in mackerel from both Dar es Salaam (3.4 mg kg${ }^{1}$ ) and Tanga $\left(3.5 \mathrm{mg} \mathrm{kg}^{-1}\right)$. In literature, Mn levels have been reported in the range of 0.09$9.23 \mathrm{mg} \mathrm{kg}^{-1}$ in the muscles of fish from Caspian sea coastal waters (Anan et al. 2005); $<0.08-9.20 \mathrm{mg} \mathrm{kg}^{-1}$ in muscles of fish from Indian markets (Sivaperumal et al. 2007), 1.28$7.40 \mathrm{mg} \mathrm{kg}^{-1}$ in fish samples from Black Seas and Aegean Sea (Uluozlu et al. 2007), 2.79$10.18 \mu \mathrm{g} \mathrm{g}^{-1}$ in muscles of fish (Mziray and Kimirei 2016). In literature, there is no information about maximum permissible levels 
of Mn in seafood but WHO has established the Provisional Table Weekly Intake (PTWI), per $\mathrm{kg}$ of body weight to be $68.6 \mathrm{mg} /$ person/week. Fish consumption data per person in Tanzania are missing, and therefore it is not possible to determine whether or not the measured elemental concentration will exceed PTWI.

The highest levels of nickel $\left(1.0 \mathrm{mg} \mathrm{kg}^{-1}\right)$ were measured in grouper, octopus and jacks from Dar es Salaam, and thumbprint emperor (1.3 $\mathrm{mg} \mathrm{kg}^{-1}$ ) from Tanga. Reported levels of $\mathrm{Ni}$ in the literature are in the range of $0.03-1.38$ $\mathrm{mg} \mathrm{kg}^{-1}$ in muscles of fish from Indian markets (Sivaperumal et al. 2007); 1.92-5.68 $\mathrm{mg} \mathrm{kg}^{-1}$ in fish samples from Black Seas and Aegean Sea (Uluozlu et al. 2007), $0.03-1.72 \mathrm{mg} \mathrm{kg}^{-1}$ in fish muscles from Mediterranean Sea (Turkmen et al. 2008), 0.12-0.15 $\mu \mathrm{g} \mathrm{g}^{-1}$ in muscles of fish (Mziray and Kimirei 2016). In literature, there is no information about maximum permissible levels of $\mathrm{Ni}$ in seafood but WHO has established the Provisional Table Weekly Intake (PTWI), per kg of body weight to be $2.45 \mathrm{mg} /$ person/week. Again, it is not possible to establish weekly intake of nickel because fish consumption data per person in Tanzania are missing.

The highest level of lead in samples from Tanga $\left(0.73 \mathrm{mg} \mathrm{kg}^{-1}\right)$ was measured in grouper. In Dar es Salaam, lead was highest $(0.80 \mathrm{mg}$ $\mathrm{kg}^{-1}$ ) in octopus. The mean levels of lead were 0.68 and $0.65 \mathrm{mg} \mathrm{kg}^{-1}$ for Dar es Salaam and Tanga, respectively. Levels of lead reported in literature are in the range of $0.33-0.93 \mu \mathrm{g} \mathrm{g}^{-1}$ in muscles of fish from Black seas and Aegean Sea (Uluozlu et al. 2007), 0.01-0.15 mg kg-1 ww for fish muscles in Portugal (Perez et al. 2001), nd-1397 $\mu \mathrm{g} \mathrm{kg}^{-1} \mathrm{ww}$ in muscles of fish from Eastern Aegean Sea (Uluturhan and Kucuksezgin 2007). The maximum permissible levels of lead in fish are $0.5-6.0 \mathrm{mg} \mathrm{kg}^{-1}$ (FAO 1983, WHO 1985), and the results of this study were within permissible levels.
Highest levels of zinc were $96.7 \mathrm{mg} \mathrm{kg}^{-1}$ in sardines from Tanga and $100.9 \mathrm{mg} \mathrm{kg}^{-1}$ in octopus from Dar es Salaam, respectively. Lowest levels of $\mathrm{Zn}$ were recorded in thumbprint emperor from Dar es Salaam (14.2 $\mathrm{mg} \mathrm{kg}^{-1}$ ) and grouper from Tanga (16.8 $\mathrm{mg} \mathrm{kg}^{-}$ $\left.{ }^{1}\right)$. Levels of $\mathrm{Zn}$ reported in literature are in the range of $1352-6693 \mu \mathrm{g} \mathrm{kg}^{-1}$ in muscle, 2710$78705 \mu \mathrm{g} \mathrm{kg}^{-1}$ in liver, and $7273-168655 \mu \mathrm{g}$ $\mathrm{kg}^{-1}$ in gonad (Uluturhan and Kucuksezgin 2007), 67.75-214.59 $\mu \mathrm{g} \mathrm{g} \mathrm{g}^{-1}$ (Mziray and Kimirei 2016). The results from this study were within the maximum permissible levels of $\mathrm{Zn}$ which range between 30 and $100 \mathrm{mg} \mathrm{kg}^{-1}$ for fish (WHO 1989).

The overall mean concentrations of $\mathrm{As}, \mathrm{Cu}$, $\mathrm{Mn}, \mathrm{Ni}, \mathrm{Pb}$ and $\mathrm{Zn}$ in the muscles of the fish species were $6.01,12.37,4.50,0.88,0.68$, $50.59 \mathrm{mg} \mathrm{kg}^{-1}$ (Table 2) and 4.46, 15.24, 4.57, $0.90,0.65$ and $50.17 \mathrm{mg} \mathrm{kg}^{-1}$ (Table 3) for Dar es Salaam and Tanga, respectively. The results indicated that the general trend in the concentrations was $\mathrm{Zn}>\mathrm{Cu}>\mathrm{As}>\mathrm{Mn}>\mathrm{Ni}>$ $\mathrm{Pb}$ for both Dar es Salaam and Tanga. According to Bahnasawy et al. (2009), fish muscles are not active tissues in accumulating heavy metals. But in polluted aquatic habitats the concentrations of metals in fish muscles may exceed the permissible limits for human consumption implying severe health threats (Kalay et al. 1999, El-Moselhya et al. 2014). Therefore, this study has focused on the muscles because they are the most consumed portions of fish by the population with not well established levels of pollution.

The variations in metal concentrations in samples between the locations (Dar es Salaam and Tanga) were assessed by One Way ANOVA test. Results indicated that there was no significant difference $(p>0.05)$ in metals concentrations in finfish and shellfish collected from the two regions. 
Shilla and Sawe - Levels of selected toxic and essential elements in fish and oysters ...

Table 2: Mean values \pm standard deviations of elemental concentrations in fish and oysters from the coast of Dar es Salaam, Tanzania. Results are reported in $\left(\mathrm{mg} \mathrm{kg}^{-1}\right)$

\begin{tabular}{|c|c|c|c|c|c|c|c|c|}
\hline \multirow{2}{*}{ English name } & \multirow{2}{*}{ Species } & \multirow{2}{*}{$\begin{array}{l}\text { Local } \\
\text { name }\end{array}$} & \multicolumn{6}{|c|}{ Elemental concentrations } \\
\hline & & & As & $\mathrm{Cu}$ & $\mathrm{Mn}$ & $\mathrm{Ni}$ & $\mathrm{Pb}$ & $\mathrm{Zn}$ \\
\hline \multicolumn{9}{|c|}{ Kunduchi Fish market } \\
\hline Mackerel $(\mathrm{n}=10)$ & Rastrelliger kanagurta & Kibua & $3.34 \pm 0.12$ & $15.03 \pm 0.21$ & $3.40 \pm 0.06$ & $0.70 \pm 0.26$ & $0.60 \pm 0.10$ & $29.10 \pm 0.55$ \\
\hline Sardines $(3 \mathrm{~kg})$ & Sardinella neglecta & Dagaa & $5.20 \pm 0.26$ & $2.90 \pm 0.66$ & $6.90 \pm 0.82$ & $0.80 \pm 0.35$ & $0.71 \pm 0.11$ & $95.70 \pm 1.40$ \\
\hline Thumbprint emperor $(\mathrm{n}=10)$ & Lethrinus harak & Changu & $5.67 \pm 0.31$ & $7.80 \pm 0.82$ & $3.60 \pm 0.06$ & $0.80 \pm 0.23$ & $0.74 \pm 0.20$ & $14.20 \pm 0.36$ \\
\hline Grouper $(\mathrm{n}=10)$ & Epinephelus lanceolatus & Chewa & $8.50 \pm 015$ & $30.53 \pm 0.47$ & $4.10 \pm 0.40$ & $1.00 \pm 0.21$ & $0.57 \pm 0.10$ & $39.54 \pm 0.66$ \\
\hline Octopus ( $2 \mathrm{~kg}$ ) & Octopus vulgaris & Pweza & $9.46 \pm 0.66$ & $13.5 \pm 0.44$ & $4.80 \pm 0.06$ & $1.00 \pm 0.32$ & $0.80 \pm 0.12$ & $100.90 \pm 0.44$ \\
\hline \multicolumn{9}{|c|}{$\begin{array}{cc}3.90 \pm 0.42 & 4.47 \pm 0.50 \\
\text { Ovster bav }\end{array}$} \\
\hline Oysters $(4 \mathrm{~kg})$ & Pinctada margaritifera & & $7.80 \pm 0.50$ & $88.50 \pm 0.32$ & $28.20 \pm 0.40$ & $2.40 \pm 0.12$ & $0.88 \pm 0.04$ & $1799.60 \pm 10.28$ \\
\hline & & $\mathrm{M}^{*}$ & 6.01 & 12.37 & 4.50 & 0.88 & 0.68 & 50.59 \\
\hline & & $\mathrm{Co} * * / \mathrm{M}^{*}$ & 1.30 & 7.15 & 6.27 & 2.72 & 1.29 & 35.57 \\
\hline
\end{tabular}

$\mathrm{M}^{*}=$ mean elemental concentration in fish; $\mathrm{Co}^{* *}=$ elemental concentration in oysters.

Table 3: Mean values \pm standard deviations of elemental concentrations in fish and oysters from the coast of Tanga, Tanzania. Results are reported in $\left(\mathrm{mg} \mathrm{kg}^{-1}\right)$.

\begin{tabular}{|c|c|c|c|c|c|c|c|c|}
\hline \multirow[b]{2}{*}{ English name } & \multirow[b]{2}{*}{ Species } & \multirow{2}{*}{$\begin{array}{l}\text { Local } \\
\text { name }\end{array}$} & \multicolumn{6}{|c|}{ Elemental concentrations } \\
\hline & & & As & $\mathrm{Cu}$ & $\mathrm{Mn}$ & $\mathrm{Ni}$ & $\mathrm{Pb}$ & $\mathrm{Zn}$ \\
\hline Mackerel $(\mathrm{n}=10)$ & Rastrelliger kanagurta & Kibua & $3.4 \pm 0.17$ & $29.70 \pm 0.61$ & $3.50 \pm 0.06$ & $0.70 \pm 0.12$ & $0.60 \pm 0.07$ & $31.40 \pm 0.98$ \\
\hline Sardines $(4 \mathrm{~kg})$ & Sardinella neglecta & Dagaa & $3.53 \pm 0.15$ & $2.67 \pm 0.42$ & $7.10 \pm 1.66$ & $1.10 \pm 0.01$ & $0.70 \pm 0.20$ & $96.70 \pm 0.50$ \\
\hline Thumbprint emperor $(\mathrm{n}=10)$ & Lethrinus harak & Changu & $4.82 \pm 0.20$ & $37.17 \pm 1.10$ & $4.10 \pm 0.05$ & $1.30 \pm 0.17$ & $0.53 \pm 0.11$ & $43.40 \pm 0.80$ \\
\hline Grouper $(n=10)$ & Epinephelus lanceolatus & Chewa & $5.63 \pm 0.15$ & $8.37 \pm 1.46$ & $4.90 \pm 0.01$ & $0.60 \pm 0.10$ & $0.73 \pm 0.30$ & $16.80 \pm 0.53$ \\
\hline Octopus (2 kg) & Octopus vulgaris & Pweza & $5.75 \pm 0.92$ & $11.70 \pm 0.62$ & $3.90 \pm 0.06$ & $0.80 \pm 0.35$ & $0.7 \pm 0.14$ & $88.90 \pm 1.88$ \\
\hline Jacks $(n=10)$ & Alectis ciliaris & Kolekole & $3.63 \pm 0.42$ & $1.80 \pm 0.20$ & $3.90 \pm 0.06$ & $0.90 \pm 0.20$ & $0.63 \pm 0.23$ & $23.80 \pm 1.04$ \\
\hline \multirow[t]{3}{*}{ Oysters (4 kg) } & Pinctada margaritifera & & $16.78 \pm 3.22$ & $269.30 \pm 4.24$ & $5.10 \pm 0.92$ & $3.50 \pm 0.24$ & $1.22 \pm 0.08$ & $3357 \pm 8.64$ \\
\hline & & $\mathrm{M}^{*}$ & 4.46 & 15.24 & 4.57 & 0.9 & 0.65 & 50.17 \\
\hline & & $\mathrm{Co}^{* *} / \mathrm{M}^{*}$ & 3.76 & 17.68 & 1.12 & 3.89 & 1.88 & 66.92 \\
\hline
\end{tabular}

$\mathrm{M}^{*}=$ mean elemental concentration in fish; $\mathrm{Co}^{* *}=$ elemental concentration in oysters. 
It is well recognized that, copper $(\mathrm{Cu})$, manganese $(\mathrm{Mn})$, nickel $(\mathrm{Ni})$ and zinc $(\mathrm{Zn})$ are essential elements, required by a wide variety of enzymes and other cell components and having vital functions in all living organisms, but very high intakes can cause adverse health problems (Demirezen and Uruc 2006). On the other hand, arsenic (As) and lead $(\mathrm{Pb})$ have no biological roles, and hence they are harmful to living organisms even at considerably low concentrations. In this study, the overall average concentrations of metals were found to accumulate in the order of $\mathrm{Zn}>\mathrm{Cu}>\mathrm{Mn}>\mathrm{As}$ $>\mathrm{Ni}>\mathrm{Pb}$ for Dar es Salaam and Tanga samples. From this trend, it is evident that the concentrations of essential elements were higher than non-essential elements which may confirm the essential roles of the former metals to the analyzed organisms. These results were in agreement with the observations of Chen and Chen (2001) $(\mathrm{Zn}=\mathrm{Fe}>\mathrm{Cu}=\mathrm{Mn}>\mathrm{Cd})$ and Bahnasawy et al. (2009) $(\mathrm{Zn}>\mathrm{Cu}>\mathrm{Pb}>\mathrm{Cd})$, although it is not always the case.

\section{Conclusions}

Results of heavy metal concentrations in edible parts of commercially important fish species have been reported and discussed. The results indicated that, zinc had the highest concentrations and arsenic had the lowest in all the analyzed species, and this indicated further that the concentrations of essential elements were higher than that of non-essential elements. The highest levels of metals were found in muscles of thumbprint emperor $(\mathrm{Cu})$, sardines ( $\mathrm{Mn}$ and $\mathrm{Zn}$ ) and octopus (As, $\mathrm{Ni}$ and $\mathrm{Pb}$ ), but there was no single metal that was consistently high for all the fish species. The elemental concentrations in oysters exceeded their respective values in the analyzed fish species by far, and this proves the usefulness of oysters as pollution bio-indicators. While the concentrations of arsenic exceeded the maximum permissible levels for fish, the concentrations of copper and zinc in the analyzed fish muscles were below the maximum permissible levels for fish recommended by various international standards and guidelines. Estimation of elemental intake from fish consumption was prevented by lack of data on the average fish intake per person in Tanzania. Results for most species and in particular oysters are reported for the first time. We acknowledge the fact that this study is based on samples from two regions and that samples from the entire coastal area could have been better. However, the study intended to gather preliminary data focusing on areas with relatively high population, industrial activities and port operations. Based on the findings of this study, it is recommended that monitoring of heavy metals in seafood should be implemented. Furthermore, we recommend studies utilizing pollution bio-indicators (marine invertebrates) to identify coastal areas that require mitigation measures for the protection of the environment and the public health.

\section{Acknowledgements}

The authors acknowledge financial support from Tanzania Atomic Energy Commission and the valuable logistic support from the University of Dar es Salaam, Department of Aquatic Science and Fisheries Technology.

\section{References}

Alhas E, Oymak SA and Akin HK 2009 Heavy metal concentrations in two barb, Barbus xanthopterus and Barbus rajanorum mystaceus from Atatürk Dam Lake, Turkey. Environ. Monit. Assess. 148(1): 11-18.

Anan Y, Kunito T, Tanabe S, Mitrofanov I and Aubrey DG 2005 Trace elements accumulation in fishes collected from coastal water of the Caspian sea. Mar. Pollut. Bull. 51: 882-888.

Ashraf MA Maah MJ Yusoff I 2012 Bioaccumulation of Heavy metals in fish species collected from former tin mining catchment. Int. J. Environ. Res. 6: 209-218.

Bahnasawy M, Khidr A and Dheina N 2009 Seasonal variations of heavy metals concentrations in mullet, Mugil cephalus and Liza ramada (Mugilidae) from Lake Manzala, Egypt. J. Aquat. Biol. Fisher. 
Shilla and Sawe - Levels of selected toxic and essential elements in fish and oysters ...

13(2): 81-100.

CAC (Codex Almentarius Commission) 1995 Joint FAO/WHO General standard for contaminants and toxins in food and feed; Amended in 2015, FAO/WHO.

Chen Y and Chen M 2001 Heavy metal concentrations in nine species of fishes caught in coastal waters off Ann-Ping, SW Taiwan. J. Food Drug Anal. 9(2): 107-114.

Chinnadurai S, Mohamed KS, Sharma J, Venkatesan V and Kripa V 2016 Assessment of bioaccumulation of bacteria in oysters from shellfish growing waters in Ashatamudi Lake (Kerala, India): a RAMSAR wetland. Reg. Stud. Mar. Sci. 7: 118-122.

Daviglus M, Sheeshka J and Murkin E 2002 Health benefits from eating fish. Comments Toxicol. 8: 345-374.

De Gieter M, Leermakers M, Van Ryssen R, Noyen J, Goeyens L, Baeyens W 2002 Total and toxic arsenic levels in North Sea fish. Arch. Environ. Contam. Toxicol. 43: 406-417.

Demirezen D and Uruc K 2006 Comparative study of trace elements in certain fish, meat and meat products. Meat Sci. 74: 255-260.

Duruibe JO, Ogwuegbu MOC and Egwurugwu J 2007 Heavy metal pollution and human biotoxic effects. Int. J. Phys. Sci. 2(5): 112118.

El-Moselhya MK, Othman AI, Abd El-Azema $\mathrm{H}$ and El-Metwally MEA 2014 Bioaccumulation of heavy metals in some tissues of fish in the Red Sea, Egypt. Egypt. J. Basic Appl. Sci. 1(2): 97-105.

EPA (United States Environmental Protection Agency) 2000 Guidance for Assessing Chemical Contaminant Data for Use in Fish Advisories, Volume 1: Fish Sampling and Analysis (Third Edition). Office of Water, EPA 823-B-00.

FAO (Food and Agriculture Organization) 1983 Compilation of legal limits for hazardous substances in fish and fishery products. FAO Fish Circular 464: 5-100.
FAO (Food and Agriculture Organization). 1993 Compilation of Legal Limits for Hazardous Substances in Fish and Fishery Products. FAO Fisheries Circular No. 764, FAO, Rome, p. 102.

FAO/WHO 2018 Food Standards Programme CODEX Committee on Contaminants in Foods. Working Document for Information and Use in Discussions Related to Contaminants and Toxins in the GSCTFF. FAO/WHO.

Fernandes C, Fontainhas-Fernandes A, Peixoto F and Salgado MA 2007 Bioaccumulation of heavy metals in Liza saliens from the Esmoriz-Paramos coastal lagoon, Portugal. Ecotoxicol. Environ. Saf. 66: 426-431.

Holynsca B and Jasion J 1986 Simultaneous determination of some trace metals in plant material by energy-dispersive X-ray fluorescence method. J. Radioanal. Nucl. Chem. 105(2): 71-77.

Jonathan MP, Munoz-Sevilla NP, GongoraGomez AM, Varela RGL, Sujitha SB, Escobedo-Urias DC, Rodriguez-Espinosa PF and Villegas LEC 2017 Bioaccumulation of trace metals in farmed pacific oysters Crassostrea gigas from SW Gulf of Califonia Coast, Mexico. Chemosphere 187: 311-319.

Kalay M, Ay O and Canil M 1999 Heavy metal concentrations in fish tissues from the Northeast Mediterranean Sea. Bull. Environ. Contam. Toxicol. 63: 673-681.

Mania M, Rebeniak M, Szynal T, Wojciechowska-Mazurek M, Starska K, Ledzion E and Postupolski J 2015 Total and inorganic arsenic in fish, seafood and seaweeds: exposure assessment. Rocz. Panstw. Zakl. Hig. 66(3): 203-210.

Mshana JG and Sekadende B 2014 Assessment of heavy metal pollution in Octopus cyanea in the coastal waters of Tanzania. J. Health Pollut. 4(6): 10-17.

Mziray P and Kimirei I 2016 Bioaccumulation of heavy metals in marine fishes (Siganus sutor, Lethrinus harak, and Rastrelliger 
kanagurta) from Dar es Salaam Tanzania. Reg. Stud. Mar. Sci. 7: 72-80.

Olgunoglu MP, Olgunoglu IA and Bayhan YK 2015 Heavy metals concentrations $(\mathrm{Cd}, \mathrm{Pb}$, $\mathrm{Cu}, \mathrm{Zn}, \mathrm{Fe})$ in giant red shrimps (Aristaeomorpha foliacea Risso 1827) from the Mediterranean Sea. Pol. J. Environ. Stud. 24: 631-635.

Perez Cid B, Boia C, Pombo L and Robelo E 2001 Determination of trace metals in fish species of the Ria de Aveiro (Portugal) by electrothermal atomic absorption spectrometry. Food Chem. 75: 93-100.

Ross DAN, Guzman HM, Potvin C and van Hinsberg VJ 2017 A review of toxic metal contamination in marine turtle tissues and its implications for human health. Reg Stud Mar Sci. 15: 1-9.

Rousseau MR, Willis PJ and Dunkan RA 1996 Practical XRF calibration procedures for major and trace elements. X-ray Spectrom. 25: 179-89.

Sivaperumal P, Sankar TV and Nair PGV 2007 Heavy metals concentrations in fish, shellfish and fish products from internal markets of India vis-à-vis international standards. Food Chem. 102: 612-620.

Tapia J, Duran E, Pena-Cortes F, Hauenstein E, Bertran C and Sclatter R 2006 Micropogonias as a bioindicator for copper in Lake Budi (IX Region, Chile). J. Chilean Chem. Soc. 51: 901-904.

Turkmen M, Turkmen A, Tepe Y, Ates A and Gokkus K 2008 Determination of metal contaminations in sea foods from Marmara, Aegean and Mediterranean seas: Twelve fish species. Food Chem. 108: 794-800.

Uluozlu OD, Tuzen M, Medil D and Soylak M 2007 Trace metal content in nine species of fish from the Black and Aegean Seas, Turkey. Food Chem. 104: 835-840.

Uluturhan E and Kucuksezgin F 2007 Heavy metals contamination in Red Pandora (Pagellus erythrinus) tissues from the eastern Aegean Sea, Turkey. Water Res. 41:
1185-1192.

URT (United Republic of Tanzania) 2001 National Bureau of Statistics and Ministry of Finance. National Accounts of Tanzania Mainland 2001-2013.

URT (United Republic of Tanzania): Basic Demographic and Socio-Economic Profile Report Tanzania Mainland. Available from: http://www.tanzania.go.tz/egov_uploads/do cuments/Tanzania_Mainland_Socio_Econo mic_Profile_sw.pdf. 2014.

URT (United Republic of Tanzania) 2010 Fisheries Sector Development Programme 2010 Ministry of Livestock and Fisheries Development. Available from: http://www.tanzania.go.tz/egov_uploads/do cuments/FSDP_sw.pdf. 2010.

Uysal K 2011 Heavy metal in edible portion (muscle and skin) and other organs (gill liver and intestine) of selected freshwater fish species. Int. J. Food Prop. 14: 280286.

Verbeke W, Sioen I, Brunsø K, De Henauw S and Van Camp J 2007 Consumer perception versus scientific evidence of farmed and wild fish: exploratory insights from Belgium. Aquacult. Int. 15(2): 121136.

Welty CJ Sousa ML Dunnivant FM Yancey PH 2018 High-density element concentrations in fish from subtidal to hadal zones of the Pacific Ocean. Heliyon 4(10): 00840 .

WHO (World Health Organization) 1985 Guidelines for drinking water quality (II): Health criteria and supporting information. WHO, Geneva, Switzerland.

WHO 1989 Heavy metals environmental aspects; Environment health criteria. No. 85. Geneva, Switzerland.

Zhou JL Salvador SM Liu YP Sequeria M 2001 Heavy metals in the tissues of dolphins (Delphinus delphs) stranded on the Portuguese coast. Sci. Total Environ. 273: 61-76. 